\title{
Carpal Bone
}

National Cancer Institute

\section{Source}

National Cancer Institute. Carpal Bone. NCI Thesaurus. Code C12688.

Any of the small bones of the wrist joint, located between the radius and the ulna and the metacarpus. 